\title{
Experimental Energy Performance of Open Cooling Towers Used Under Low and Variable Approach Conditions for Indirect Evaporative Cooling of Buildings
}

\author{
Ben Costelloe \\ Technological University Dublin, ben.costelloe@tudublin.ie \\ Donal Finn \\ University College Dublin, donal.finn@ucd.ie
}

Follow this and additional works at: https://arrow.tudublin.ie/engschcivart

Part of the Education Commons, Environmental Design Commons, Mechanical Engineering Commons, Technology and Innovation Commons, and the Thermodynamics Commons

\section{Recommended Citation \\ Costelloe, B., Finn., D.: Experimental Energy Performance of Open Cooling Towers Used Under Low and Variable Approach Conditions for Indirect Evaporative Cooling of Buildings. Building Services Engineering Research and Technology, vol. 24 no. 3 p.163-177. doi:10.1191/0143624403bt069oa}

This Article is brought to you for free and open access by the School of Civil and Structural Engineering at ARROW@TU Dublin. It has been accepted for inclusion in Articles by an authorized administrator of ARROW@TU

Dublin. For more information, please contact arrow.admin@tudublin.ie, aisling.coyne@tudublin.ie, gerard.connolly@tudublin.ie. Funder: CIBSE, Enterprise Ireland, DIT Seed Fund 


\section{Building Services Engineering Research and Technology}

Experimental energy performance of open cooling towers used under low and variable approach conditions for indirect evaporative cooling in buildings B Costelloe and D Finn

BUILDING SERV ENG RES TECHNOL 2003 24: 163

DOI: 10.1191/0143624403bt069oa

The online version of this article can be found at:

http://bse.sagepub.com/content/24/3/163

\section{Published by:}

(\$)SAGE

http://www.sagepublications.com

On behalf of:

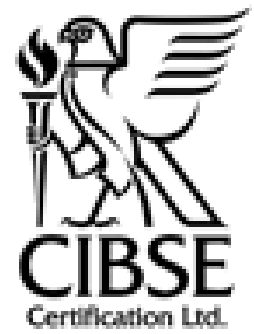

The Chartered Institution of Building Services Engineers

Additional services and information for Building Services Engineering Research and Technology can be found at:

Email Alerts: http://bse.sagepub.com/cgi/alerts

Subscriptions: http://bse.sagepub.com/subscriptions

Reprints: http://www.sagepub.com/journalsReprints.nav

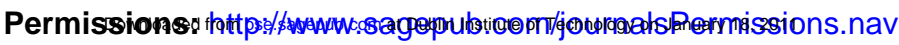




\title{
Experimental energy performance of open cooling towers used under low and variable approach conditions for indirect evaporative cooling in buildings
}

\author{
B Costelloe ${ }^{a}$ BA MSc CEng MInstE MCIBSE and D Finn' ${ }^{b}$ BE MEngSc PhD CEng MASHRAE \\ ${ }^{a}$ Department of Building Services Engineering, Dublin Institute of Technology, Ireland \\ ${ }^{b}$ Department of Mechanical Engineering, University College Dublin, Ireland
}

\begin{abstract}
The success of chilled ceilings and displacement ventilation systems as a means of sensible cooling in buildings has prompted a review of evaporative cooling technology as an effective means of generating the required cooling water. When such cooling water is generated at low approach conditions (2-5 K), at the higher temperatures required in these systems $\left(14-18^{\circ} \mathrm{C}\right)$, very high levels of availability result. In many north western European locations the levels of availability are such that the prospect of supplanting rather than simply supplementing the refrigeration system, for sensible cooling purposes, arises. The viability of the technique, however, largely depends on achieving low approach conditions, at acceptable levels of energy performance. Hence the need to investigate the energy performance of the process. This paper presents the results of recent experimental research into: i) the achievement of low approach conditions in an evaporative cooling test rig; and ii) the energy performance of this test rig when generating cooling water, indirectly, at the temperatures required for chilled ceilings. Energy performance is presented for a range of specific conditions and typical annual efficiencies of cooling water generation are determined. Results are compared with typical energy efficiencies of conventional, vapour compression based, refrigeration systems. A significant potential for improved annual energy performance, is shown.
\end{abstract}

\section{List of symbols}

$T_{\mathrm{pf}}$

$T_{\mathrm{pr}}$

$T_{\mathrm{sf}}$

$T_{\mathrm{sr}}$

$T_{\mathrm{wb}}$

$T_{\mathrm{pa}}$ ${ }^{\circ} \mathrm{C}$ primary loop flow temperature ${ }^{\circ} \mathrm{C}$ primary loop return temperature ${ }^{\circ} \mathrm{C}$ secondary loop flow temperature ${ }^{\circ} \mathrm{C}$ secondary loop return temperature ${ }^{\circ} \mathrm{C}$ ambient wet bulb temperature (WBT) primary approach temperature (PAT) $\mathrm{K}$
$T_{\mathrm{sa}} \quad$ secondary approach temperature (SAT) K

$Q \quad$ accumulated cooling energy in test period $\mathrm{kWh}$

$P_{\mathrm{f}} \quad$ accumulated fan energy input in test period $\mathrm{kWh}$

$P_{\mathrm{p}} \quad$ accumulated pump energy input in test period $\mathrm{kWh}$

$W_{\mathrm{f}} \quad$ fan power input $\mathrm{kW}$

COP coefficient of performance (dimensionless)

\section{Introduction}

Address for correspondence: B. Costelloe, Department of Building Services Engineering, Dublin Institute of Technology, Bolton Street, Dublin 1, Ireland. E-mail: ben.costelloe@ dit.ie

Concern with environmental emissions and global energy consumption has lead to the develop- 
ment of low energy cooling technologies, among them evaporative cooling, as an alternative to the use of refrigeration in buildings for general sensible cooling. ${ }^{1}$ Cooling of buildings by means of water evaporation has traditionally been seen as appropriate mainly in hot and arid climates. ${ }^{2}$ The technique has had very limited application in maritime and temperate climates where the ambient relative humidity is often high. However, the recent success of chilled ceilings, as an effective means of cooling buildings has prompted a review of the evaporative cooling technique as an effective supplement to, or even a substitute for, refrigeration based sensible cooling.

While the evaporative cooling technique can be exploited with any water based building cooling system, such as the commonly used fan coil system, the technique is particularly advantageous when a chilled ceiling system is used, due to the higher cooling water temperatures which are employed. Chilled ceiling systems generally require cooling water at $14-18^{\circ} \mathrm{C}$. Conditions vary, but a typical design arrangement would be a supply temperature of $15^{\circ} \mathrm{C}$ with a $3^{\circ} \mathrm{C}$ rise, returning at $18^{\circ} \mathrm{C}$. A research project $^{3}$ which investigated thermal comfort conditions maintained in a test room, with internal heat gains of $60 \mathrm{~W} / \mathrm{m}^{2}$ and served by a chilled ceiling, established that cooling water, supplied to the ceiling, at a temperature as high as $18^{\circ} \mathrm{C}$ could maintain a satisfactory comfort index (a maximum dry resultant temperature of $25.2^{\circ} \mathrm{C}$ and a maximum predicted mean vote of +0.8 ) in the space. This maximum condition was measured between 16:00 and 17:00 hours with lower conditions at other times. This was considered acceptable, as it implies a predicted percentage dissatisfied of no greater than $20 \%$ for short periods. A temperature of $18^{\circ} \mathrm{C}$ would seem to be the maximum cooling water temperature which can be used with sensible cooling systems, of this type, although this largely depends on the comfort criteria considered acceptable for each project and whether an adaptive approach to comfort conditions could be employed. Two recent research papers state that chilled ceiling radiant panels can operate with a supply water temperature as high as $18-20^{\circ} \mathrm{C} .4,5$

Some recent work ${ }^{6,7}$ on raising the cooling output of chilled ceiling panels, above the current level of $70 \mathrm{~W} / \mathrm{m}^{2}$, is also relevant. An increase in panel cooling output will allow similar loads to be cooled by higher cooling water temperatures. This work suggests that chilled ceiling panel cooling outputs may increase to $100 \mathrm{~W} / \mathrm{m}^{2}$ (at $10 \mathrm{~K}$ panel surface to room air temperature difference) as a result of a change in panel design, from the rear mounted coiled tube, to the more integrated rectangular waterway, which increases heat transfer and leads to a more uniform panel surface temperature.

Figure 1, which shows a simplified schematic of a typical indirect evaporative cooling system, indicates the relevant design parameters. An important performance parameter is the primary approach temperature (PAT) which is equal to $T_{\mathrm{pf}}-T_{\mathrm{wb}}$. This aspect is complicated by the requirement, in contemporary applications, to separate the tower water circuit from the building cooling circuit by means of a heat exchanger. Hence the significant performance parameter becomes the secondary approach temperature (SAT) which is equal to $T_{\mathrm{sf}}-T_{\mathrm{wb}}$.

The importance of the SAT, for evaporative cooling systems, is demonstrated in Figure 2, which shows the impact of reducing the SAT on the percentage total annual availability of cooling water, for the possible range of cooling water temperatures, generated by evaporation, in Dublin. ${ }^{8}$ Examining this figure it can be seen, for example, that at a secondary flow ( $T_{\text {sf, }}$, see Figure 1) cooling water temperature of $16^{\circ} \mathrm{C}$, the total annual availability increases from $50 \%$ at $8 \mathrm{~K} \mathrm{SAT}$ to $88 \%$ at $3 \mathrm{~K} \mathrm{SAT}$. While the relationship between SAT and percentage annual availability differs for each location, the impact of reducing the SAT on availability is generally considerable in European locations. In Milan, for example, as shown in Figure 3, a similar reduction in SAT, at $16^{\circ} \mathrm{C}$ cooling water temperature, will increase total availability from $37 \%$ to $57 \%{ }^{8}$ Similar charts can be produced for other locations. 


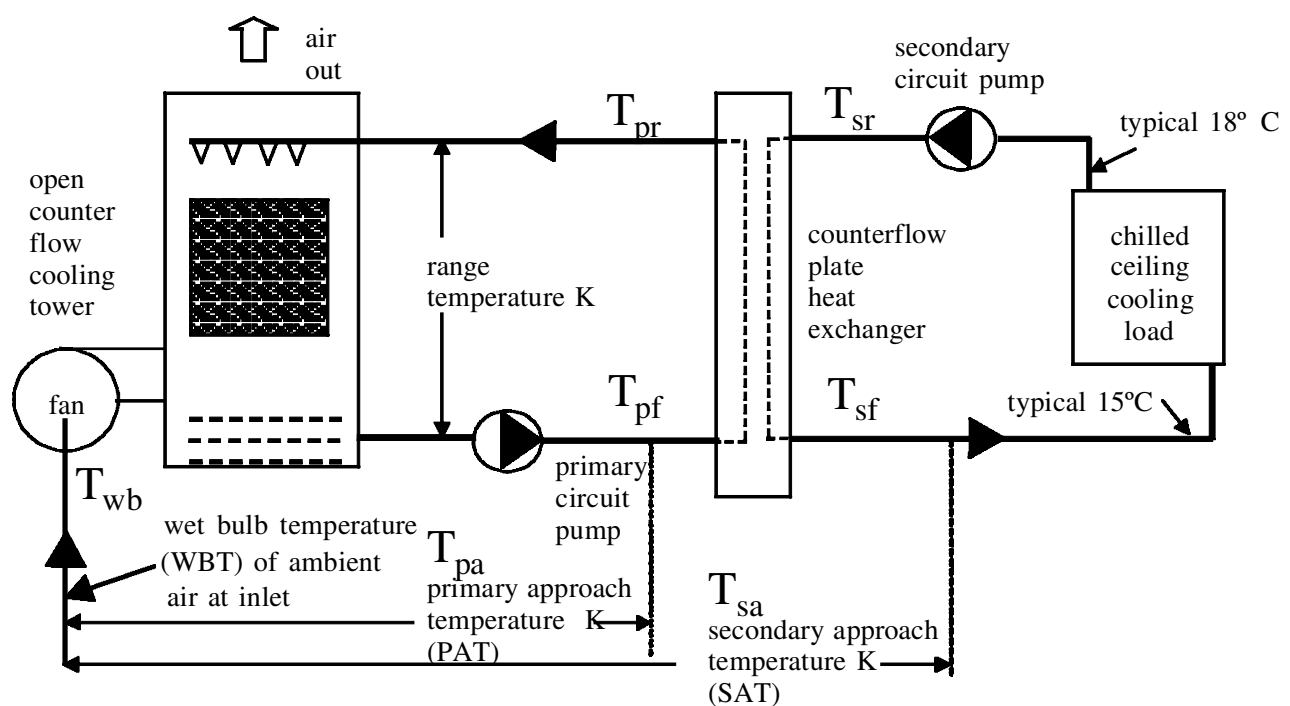

Figure 1 Simplified schematic of indirect evaporative cooling system with an open tower

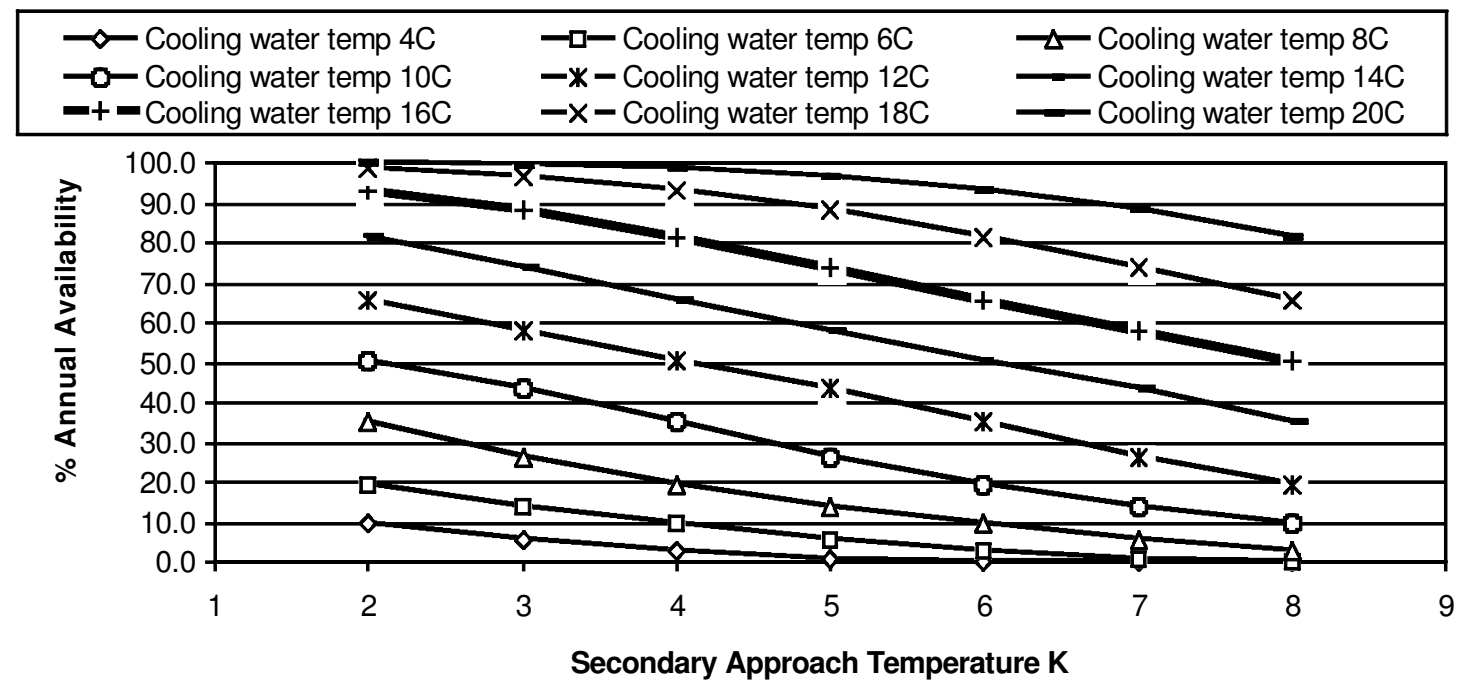

Figure 2 Impact of secondary approach temperature on percentage total annual availability of cooling water, in Dublin, for a range of cooling water temperatures $\left({ }^{\circ} \mathrm{C}\right)^{8}$

As shown in Figure 2 cooling water at $18^{\circ} \mathrm{C}$ has statistically a total availability level of $96.3 \%$ in Dublin, provided a low SAT of $3 \mathrm{~K}$ can be achieved. While cooling water at $18^{\circ} \mathrm{C}$ used in chilled ceilings can successfully cool buildings with internal loads of up to $60 \mathrm{~W} / \mathrm{m}^{2}$, it can also be used to cool the supply air to buildings to $20^{\circ} \mathrm{C}$, provided a suitable design of cooling coil is used. ${ }^{2}$ Supply air at $20^{\circ} \mathrm{C}$ can be used in displacement ventilation systems to supplement the cooling provided by the chilled ceiling system. With such a combination, cooling loads of the order of $80 \mathrm{~W} / \mathrm{m}^{2}$ can be treated. However, when displacement ventilation is combined with chilled ceilings the cooling contribution of the ventilation system needs to be limited to 


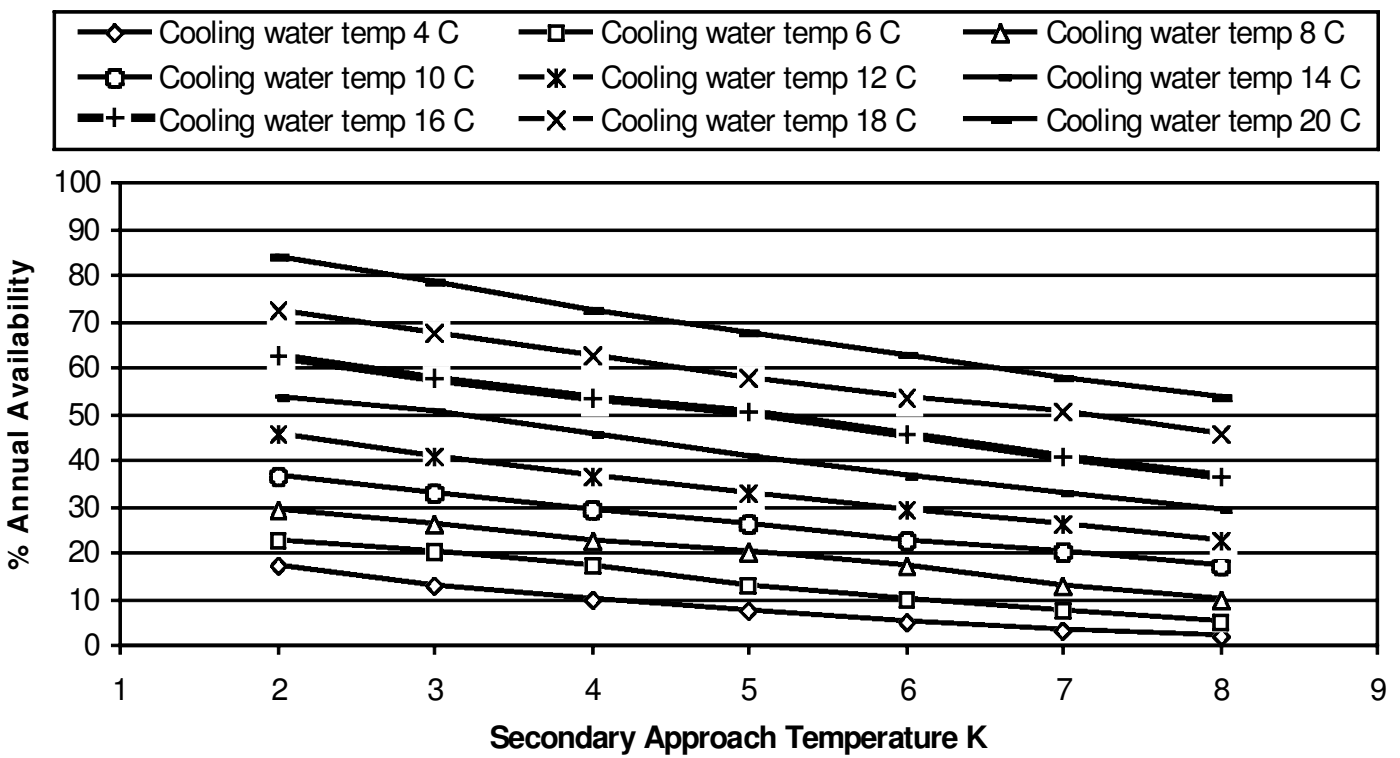

Figure 3 Impact of secondary approach temperature on percentage total annual availability of cooling water, in Milan, for a range of cooling water temperatures $\left({ }^{\circ} \mathrm{C}\right)^{8}$

approximately $25 \%$ of the sensible load if high levels of ventilation efficiency are to be maintained..$^{9}$ Sensible cooling loads of this magnitude are common in many commercial buildings, with standard internal loads and constructed using high performance building envelopes, in temperate European regions.

Cooling water at $18^{\circ} \mathrm{C}$ and $3 \mathrm{~K} \mathrm{SAT}$ is statistically unavailable for just $320 \mathrm{~h}$ out of a possible $8760 \mathrm{~h}$ per annum in Dublin. ${ }^{10}$ The extent of this availability is so wide that it comes very close to providing year-round cooling. Table 1 (in ascending order of the wet bulb temperature (WBT) shows the $1 \%$ external design conditions for some cities in north western Europe with temperate and maritime climates. ${ }^{11}$ All these cities have similar external design WBTs, but different dry bulb temperatures (DBTs) and would, therefore, have approximately similar levels of cooling water availability in summer at similar SATs.

This raises the prospect that the evaporative cooling technique, either acting alone or in conjunction with other low energy cooling strategies

Table 1 One per cent design conditions for north western European cities with temperate and maritime climates ${ }^{11}$

\begin{tabular}{llllll}
\hline City & $1 \%$ DBT ${ }^{\circ} \mathrm{C}$ & $\begin{array}{l}\text { Mean coincident } \\
\text { WBT }{ }^{\circ} \mathrm{C} \text { (coincident } \\
\text { with DBT) }\end{array}$ & $\begin{array}{l}1 \% \text { WBT }{ }^{\circ} \mathrm{C} \\
1 \% \text { humidity } \\
\text { ratio } \mathrm{g} / \mathrm{kg}\end{array}$ & $1 \%$ dew point ${ }^{\circ} \mathrm{C}$ \\
\hline Glasgow & 21.6 & 16.0 & 16.7 & 10.7 & 15.0 \\
Belfast & 20.7 & 15.9 & 16.8 & 11.1 & 15.5 \\
Dublin & 20.6 & 16.3 & 17.1 & 11.4 & 15.9 \\
Copenhagen & 23.2 & 16.4 & 17.4 & 11.0 & 15.5 \\
Oslo (Fernebo) & 24.8 & 16.4 & 17.4 & 11.2 & 15.8 \\
Manchester & 23.1 & 16.4 & 17.4 & 11.3 & 15.7 \\
Helsinki & 24.1 & 16.3 & 17.6 & 11.4 & 15.9 \\
Plymouth & 22.1 & 16.6 & 17.6 & 11.9 & 16.6 \\
Stockholm (Bromma) & 24.2 & 16.2 & 17.7 & 11.5 & 16.1 \\
Tallinn & 23.3 & 16.9 & & 11.7 & 16.3 \\
\hline
\end{tabular}


(such as night ventilation or fabric thermal storage), can supplant rather than simply supplement the requirement for refrigeration based sensible cooling. For this to occur the evaporative cooling system must be used in conjunction with a 'high temperature' building cooling system and a low approach condition must be achieved in the cooling tower and heat exchanger, particularly during the warmer months. This in turn requires a high air and water mass flow rate in the cooling tower per unit of load which itself has the potential to raise the energy consumption of the process. The success of this strategy, therefore, largely depends on achieving low approach conditions in the heat rejection system, at viable levels of primary energy consumption.

An important issue, that merits mention in the context of current health and safety concerns is the considerably lower cooling tower water temperatures required in this application, in comparison with cooling towers used to reject heat from refrigeration condensers. The cooling tower primary water temperature will generally not exceed $20^{\circ} \mathrm{C}$ when operating in summer. Hence the possibilities for the growth of the bacterium Legionella pneumophila are minimal, compared with conventional refrigeration condenser water cooling towers, in which water temperatures are normally in the high growth range of $27-33^{\circ} \mathrm{C}$. The optimum temperature for growth of the bacterium being $37^{\circ} \mathrm{C}$. At temperatures above $37^{\circ} \mathrm{C}$, the rate of multiplication of the organism decreases and ceases at $46^{\circ} \mathrm{C}$. Below $37^{\circ} \mathrm{C}$ the multiplication rate decreases and it can be considered insignificant below $20^{\circ} \mathrm{C} .{ }^{12}$ Nevertheless water treatment is advisable, and is required in any event to limit scale and corrosion. This fact is important in promoting greater confidence in the use of cooling towers for evaporative cooling, particularly in commercial buildings.

\section{Background}

The use of indirect evaporative cooling systems, using cooling towers, was first reported in Arizona in the 1920s. ${ }^{2}$ While water side evaporative cooling arrangements are occasionally used today with air-water systems, the use of the technique is well short of its potential. ${ }^{13}$ The lack of in-depth knowledge of the energy performance of water side free cooling systems has been identified by Field ${ }^{14}$ as a barrier to the wider use of the technique.

The traditional approach to indirect water side evaporative cooling is to apply the technology in the context of a changeover system, ${ }^{13}$ at standard cooling water temperatures, typically $7^{\circ} \mathrm{C}$. By routing the cooling tower water and the cooling load water through a plate heat exchanger the condenser and evaporator circuits are bypassed, providing cooling without operating the refrigeration compressor. The extent of the annual energy savings vary greatly with each project, but are typically of the order of $30 \%$ less than a non changeover system. With such systems, building cooling is largely by refrigeration. In recent years some measures have been taken to extend the period for which evaporative cooling is effective. ${ }^{15}$ However, traditional low temperature cooling systems are used.

The following factors have been identified as limiting the widespread application of this technology, particularly in the temperate and maritime climate of north western Europe.

1) Availability levels, for conventional cooling water temperatures, generated by evaporation, are generally low. For example, even on the basis of a $3 \mathrm{~K} \mathrm{SAT}$, cooling water at $7^{\circ} \mathrm{C}$ can statistically be generated in Dublin for only $22 \%$ of the year. However, cooling water at $15^{\circ} \mathrm{C}$ can be produced for $81 \%$ and at $18^{\circ} \mathrm{C}$ for $96 \%$ of the year. With conventional cooling water temperatures capital investment is required in both refrigeration and changeover plant and controls, for a very limited return in availability.

2) The seasonal stability associated with large continental land mass climates, which is absent in maritime climates, and the experience of other large changeover systems, in maritime climates, has not encouraged con- 
fidence in changeover arrangements, from an operational point of view.

3) The increase in the use of air-cooled chilling plants, at the expense of water cooled condensers, particularly for smaller loads, subsequent to the first recognized outbreak of Legionnaires' disease in July 1976, has favoured the use of dry cooling as a means of improving the energy efficiency of refrigeration plants.

The application of evaporative cooling to water based, high temperature, sensible cooling systems, in general, and to chilled ceilings in particular, offers the prospect of eliminating the changeover requirement and therefore of overcoming these limitations. The objective is to maximize evaporative cooling and to look to other low energy cooling strategies during those periods when the cooling water temperature generated is above the design level.

Two approaches have been developed to this form of indirect evaporative cooling - closed wet cooling towers and open towers with separate plate heat exchangers. Each arrangement has advantages in particular circumstances. The thermal performance of closed towers in this application has been investigated experimentally ${ }^{5}$ and using CFD. ${ }^{4}$ This work does not include, however, an assessment of energy performance. Computational modelling work has been completed recently on the energy performance of closed wet cooling towers, in this application. ${ }^{16}$ In this work COP levels ranging from 3 to 20 were indicated, depending on the level of heat rejected and tower air velocity, with a predicted COP of 4.6 for the nominal tower design data. In this study, also, it is shown that the COP level could be optimized to 11.4 by increasing the heat transfer area (quantity of coil rows and tubes) and reducing the air velocity. A subsequent simulation study, based on the optimized heat transfer area, and applied to an office building in Zurich indicated a COP of 8.4, for the cooling period April to October. There is, however, a need for experimental research on the energy performance of open and closed towers, in this application. Two experimental research issues arise in this context: i) is it technically feasible to generate cooling water at such low approach conditions; and ii) can such cooling water be generated at viable levels of annual energy consumption? To investigate these issues an automated experimental research facility has been designed and constructed at the Dublin Institute of Technology, as shown in Figure 4.

\section{Experimental test rig}

The test rig includes a prototype cooling tower, with three packing sections and a laboratory test rig with automatic data logging of key variables. A schematic diagram of the rig, which includes the measured conditions is shown in Figure 4. The open counter-flow cooling tower and the plate heat exchanger are optimized for close approach conditions. The electrical energy consumption of all power consuming equipment is individually measured. Modulated speed control of the cooling tower fan is achieved by inverter control of the fan motor. The cooling load is provided by an in-line electric immersion heater, with modulated thyristor control. This enables the imposed cooling load on the tower to be accurately measured and controlled. The design of the rig is described elsewhere. ${ }^{17}$

\section{Experimental test programme results}

The measured results are first presented for the tests on the technical feasibility of very low approach conditions. Secondly the results of the energy performance tests are presented.

\subsection{Feasibility of low approach conditions}

A series of tests was conducted to investigate the technical feasibility of achieving low approach temperatures in the primary and secondary circuits. Three imposed constant cooling loads of $24 \mathrm{~kW}, 20 \mathrm{~kW}$ and $15 \mathrm{~kW}$ were used, by setting the thyristor at the appropriate value. The ambient WBT ranged from $6.4^{\circ} \mathrm{C}$ to $16.5^{\circ} \mathrm{C}$ during the course of the tests. As the objective was to minimize the approach condition at the 


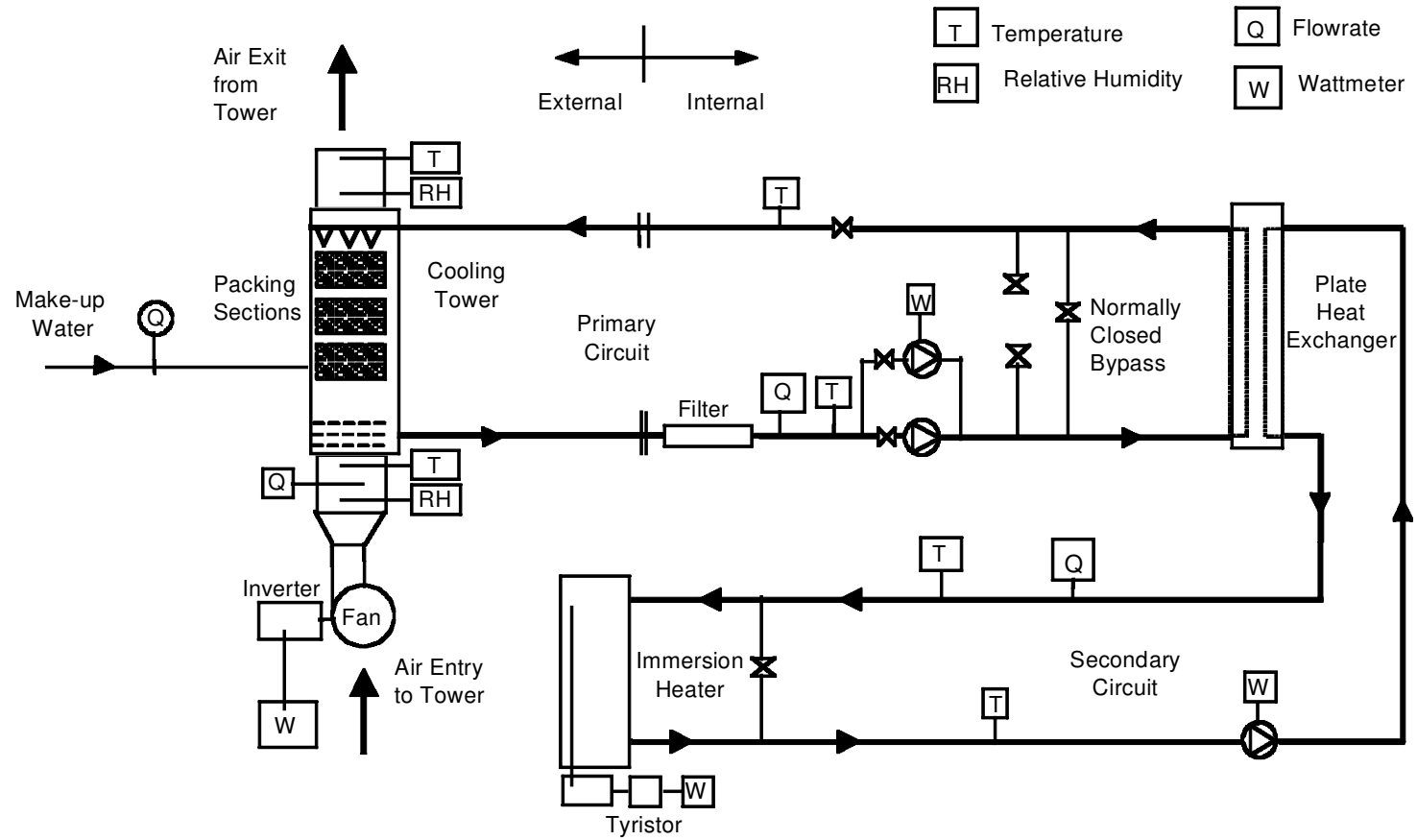

Figure 4 Schematic diagram of evaporative cooling experimental test rig with open tower

tower, the tower air volume flow rate was set to maximum and all three packing sections were used. The cooling tower range temperature (see Figure 1) affects the approach condition achieved, hence the primary circuit water volume flow rate was set to maximum to minimize the range temperature. The secondary circuit volume flow rate was also set to maximum to minimize the heat exchanger approach condition and thereby minimize the SATs for the rig as a whole. The test results are summarized in Table 2. Primary approach temperatures (PAT) ranging from 0.9 to $2.3 \mathrm{~K}$ were measured depending on imposed load and ambient condition. SATs ranging from 2.2 to $4.3 \mathrm{~K}$ were measured. These results indicate that a SAT of $3 \mathrm{~K}$ is clearly feasible with an imposed cooling load of $20 \mathrm{~kW}$. In general, therefore, this implies a heat rejection rate of $1 \mathrm{~kW}$ per $0.05 \mathrm{~m}^{3}$ or a load/volume ratio of $20 \mathrm{~kW} / \mathrm{m}^{3}$ of packing, based on the packing surface area of $200 \mathrm{~m}^{2} / \mathrm{m}^{3}$, or $10 \mathrm{~m}^{2}$ per $\mathrm{kW}$ of heat rejected, which is technically quite feasible.

\subsection{Energy viability of low approach conditions}

The energy performance of the process can be assessed in terms of the energy coefficient of performance (COP) or the cooling energy produced, per unit of electrical energy input to the cooling tower fan and primary circuit pump. The primary circuit pump energy has been included in this definition as the range temperature needs to be low (and hence the primary circuit mass flow rate per unit of load is high) in order to achieve low approach conditions. For the purpose of the research tests this parameter can be defined as:

$$
\mathrm{COP}=Q /\left(P_{\mathrm{f}}+P_{\mathrm{p}}\right)
$$

In general, building secondary cooling systems, require cooling water at a constant design temperature throughout the year. The cooling water temperature cannot be allowed to fall, if condensation is to be avoided on chilled ceilings or dry secondary coils. Furthermore, chilled ceilings 
Table 2 Summary of low approach experimental test results from the evaporative cooling test rig (Dublin)

\begin{tabular}{|c|c|c|c|c|c|}
\hline $\begin{array}{l}\text { Nominal } \\
\text { load } \\
(\mathrm{kW})\end{array}$ & $\begin{array}{l}\text { Ambient } \\
\text { WBT } \\
\left({ }^{\circ} \mathrm{C}\right)\end{array}$ & $\begin{array}{l}\text { Primary flow } \\
\text { temperature from } \\
\text { tower } \\
\left({ }^{\circ} \mathrm{C}\right)\end{array}$ & $\begin{array}{l}\text { Secondary flow } \\
\text { temperature from } \\
\text { heat exchanger } \\
\left({ }^{\circ} \mathrm{C}\right)\end{array}$ & $\begin{array}{l}\text { Primary approach } \\
\text { to WBT (PAT) } \\
\text { (K) }\end{array}$ & $\begin{array}{l}\text { Secondary } \\
\text { approach } \\
\text { to WBT (SAT) } \\
\text { (K) }\end{array}$ \\
\hline 24 & 6.4 & 8.7 & 10.7 & 2.3 & 4.3 \\
\hline 24 & 8.9 & 10.8 & 12.5 & 1.9 & 3.6 \\
\hline 24 & 9.2 & 11.1 & 12.8 & 1.9 & 3.6 \\
\hline 24 & 11.1 & 12.8 & 14.6 & 1.7 & 3.5 \\
\hline 20 & 8.4 & 9.8 & 11.3 & 1.4 & 2.9 \\
\hline 20 & 9.2 & 10.6 & 12.1 & 1.4 & 2.9 \\
\hline 20 & 10.2 & 11.3 & 12.9 & 1.1 & 2.7 \\
\hline 20 & 12.5 & 13.5 & 15.1 & 1.0 & 2.6 \\
\hline 20 & 16.5 & 17.4 & 19.0 & 0.9 & 2.5 \\
\hline 15 & 8.7 & 9.7 & 10.9 & 1.0 & 2.2 \\
\hline 15 & 9.3 & 10.6 & 11.7 & 1.3 & 2.4 \\
\hline 15 & 9.7 & 11.1 & 12.3 & 1.4 & 2.6 \\
\hline 15 & 10.6 & 11.6 & 12.8 & 1.0 & 2.2 \\
\hline
\end{tabular}

have also been shown to have a significant degree of self-regulation, ${ }^{18}$ with an increased cooling output as room conditions rise at a constant design cooling water flow temperature. This feature enables the energy performance of the evaporative cooling process to be improved at lower ambient WBT, as the cooling tower air volume flow rate can be reduced, which increases the approach condition, but maintains the required design cooling water temperature. The objective of the tests, therefore, was to measure the energy performance of the heat rejection process, not only at minimum or design approach conditions but also across a typical range of 3-10 K SAT. The energy performance needs to be assessed, in the first instance, at a constant full cooling load $(24 \mathrm{~kW})$ at various approach conditions. Secondly, in order to simulate the situation in which a partial cooling load was imposed on the tower, the same series of tests were repeated at a constant partial load of $70 \%$ of the full load $(17 \mathrm{~kW})$. This would represent the situation in a building in which the load was reduced due to a reduced internal load, or the absence of an external load.

The test method used was to select a particular cooling load by setting the thyristor at a particular output. This load remained constant during a series of tests in which the fan power was pro- gressively reduced by altering the cooling tower fan motor, inverter set point, for each test. The cooling load was then altered and a further series of tests repeated at the same series of fan power levels. The electrical energy consumption of the cooling tower fan, primary pump and immersion heater was automatically measured and accumulated. During all tests the primary and secondary water volume flow rates remained constant. The power input to the secondary pump was not considered in the energy performance assessment (see Equation 1) on the basis that a secondary circuit pump is required whether cooling is provided by evaporation or vapour compression refrigeration.

A series of 11 test runs were completed. The test results are summarized in Table 3 . Five tests were run at a constant nominal cooling load of $24 \mathrm{~kW}$ (tests 1-5) and with a fan power consumption of $100 \%, 75 \%, 60 \%, 32 \%$, and $20 \%$ of the maximum value. A further five tests (tests 6-10) were repeated at similar fan power conditions but with a nominal load of $17 \mathrm{~kW}$, representing a $70 \%$ partial load condition. One further test (test 11) was carried out at a nominal load of $17 \mathrm{~kW}$ but with a fan power consumption of $16 \%$, which represents the minimum practical fan power consumption level. Ambient WBT ranged from 8 to $14^{\circ} \mathrm{C}$ during the course of the 
Table 3 Summary of results of energy performance tests on evaporative cooling test rig

\begin{tabular}{|c|c|c|c|c|c|c|c|}
\hline $\begin{array}{l}\text { Test } \\
\text { no. }\end{array}$ & $\begin{array}{l}\text { Cooling } \\
\text { tower fan } \\
\text { power } \\
(\%)\end{array}$ & $\begin{array}{l}\text { Accumulated } \\
\text { cooling energy effect } \\
\text { (load rejected) } \\
\text { (kWh) }\end{array}$ & $\begin{array}{l}\text { Accumulated } \\
\text { energy input to } \\
\text { tower fan } \\
\text { (kWh) }\end{array}$ & $\begin{array}{l}\text { Accumulated } \\
\text { energy input to } \\
\text { primary pump } \\
\text { (kWh) }\end{array}$ & $\begin{array}{l}\text { Average } \\
\text { PAT } \\
\text { achieved } \\
\text { (K) }\end{array}$ & $\begin{array}{l}\text { Average } \\
\text { SAT } \\
\text { achieved } \\
\text { (K) }\end{array}$ & $\begin{array}{l}\text { Test } \\
\text { COP }\end{array}$ \\
\hline 1 & 100 & 48.2 & 5.0 & 1.4 & 1.2 & 4.4 & 7.5 \\
\hline 2 & 75 & 45.3 & 3.8 & 1.3 & 1.3 & 4.4 & 8.9 \\
\hline 3 & 60 & 47.9 & 2.9 & 1.3 & 1.7 & 4.8 & 11.4 \\
\hline 4 & 32 & 47.0 & 1.6 & 1.3 & 4.4 & 7.4 & 16.2 \\
\hline 5 & 20 & 47.0 & 1.0 & 1.3 & 6.2 & 9.4 & 20.4 \\
\hline 6 & 100 & 34.4 & 5.1 & 1.3 & 1.0 & 3.0 & 5.4 \\
\hline 7 & 75 & 35.0 & 3.8 & 1.2 & 1.0 & 2.9 & 7.0 \\
\hline 8 & 60 & 35.0 & 3.0 & 1.3 & 1.5 & 3.8 & 8.1 \\
\hline 9 & 32 & 33.9 & 1.6 & 1.3 & 2.5 & 4.7 & 11.7 \\
\hline 10 & 20 & 34.1 & 1.1 & 1.3 & 4.1 & 6.5 & 14.2 \\
\hline 11 & 16 & 34.1 & 0.8 & 1.3 & 5.5 & 7.8 & 16.2 \\
\hline
\end{tabular}

tests. At a full load of $24 \mathrm{~kW}$ and with a SAT ranging from 4.4 to $4.8 \mathrm{~K}$, a COP ranging from 7.5 to 11.4 was achieved. At a partial load of 17 $\mathrm{kW}$ and with a SAT ranging from 2.9 to $4.7 \mathrm{~K}$, a COP ranging from 5.4 to 11.7 was achieved. These energy performance levels demonstrate that the technique is clearly viable at the low approach conditions, which have been shown to be technically feasible.

Over the course of the tests very small changes occurred in water and air density, due to small changes in the ambient dry bulb condition. These are not significant, as the range of ambient DBT was small, from 10 to $20^{\circ} \mathrm{C}$ over the course of the tests, with a maximum variation in air density of $4.3 \%$ for this temperature range. There is also some evidence that the approach condition has a small dependence on the absolute value of the ambient WBT. ${ }^{5}$ The approach condition seems to fall marginally as the absolute value of the ambient WBT rises. The decrease in the approach condition is linear and is reported as approximately $8 \%$ as the ambient WBT rises from 10 to $20^{\circ} \mathrm{C}$. In the case of these tests the ambient WBT varied from 8 to $14^{\circ} \mathrm{C}$. Hence the variation in the approach condition, due to this effect, over this test range is in the order of $5 \%$ and will not materially affect the calculated energy performance. The results shown in Table 2 (for the 24 and $20 \mathrm{~kW}$ load) indicate a similar trend to that reported by Facao and Oliveira. ${ }^{5}$ A small variation in the supply voltage of up to $4 \%$ can also have slight effects on the output of the electric heater, which are also not significant.

\section{Discussion of results}

While a summary of each test result is given in Table 3, it is useful to investigate some of the test results in more detail and examine the variation in the measured conditions over the course of a full day. For this purpose test 4 and test 7 have been selected as being representative of the range of conditions tested. These results are shown in Figures 5 and 6. Figure 5 shows the results for a full $24 \mathrm{~kW}$ cooling load at $32 \%$ fan power and 7.4 K SAT, while Figure 6 shows the results for a $17 \mathrm{~kW}$ cooling load at $75 \%$ fan power and $2.9 \mathrm{~K} \mathrm{SAT}$. Both figures show the variation in conditions over a $9 \mathrm{~h}$ period. In both Figures 5 and 6 a secondary flow temperature between 15 and $17^{\circ} \mathrm{C}$ was maintained throughout the day, demonstrating the suitability of the process for radiant cooling applications and chilled ceilings generally.

Figures 5 and 6 also show how the secondary, flow temperature tracks the ambient WBT, rather than the more widely fluctuating ambient DBT. This close tracking, which is evident in both 


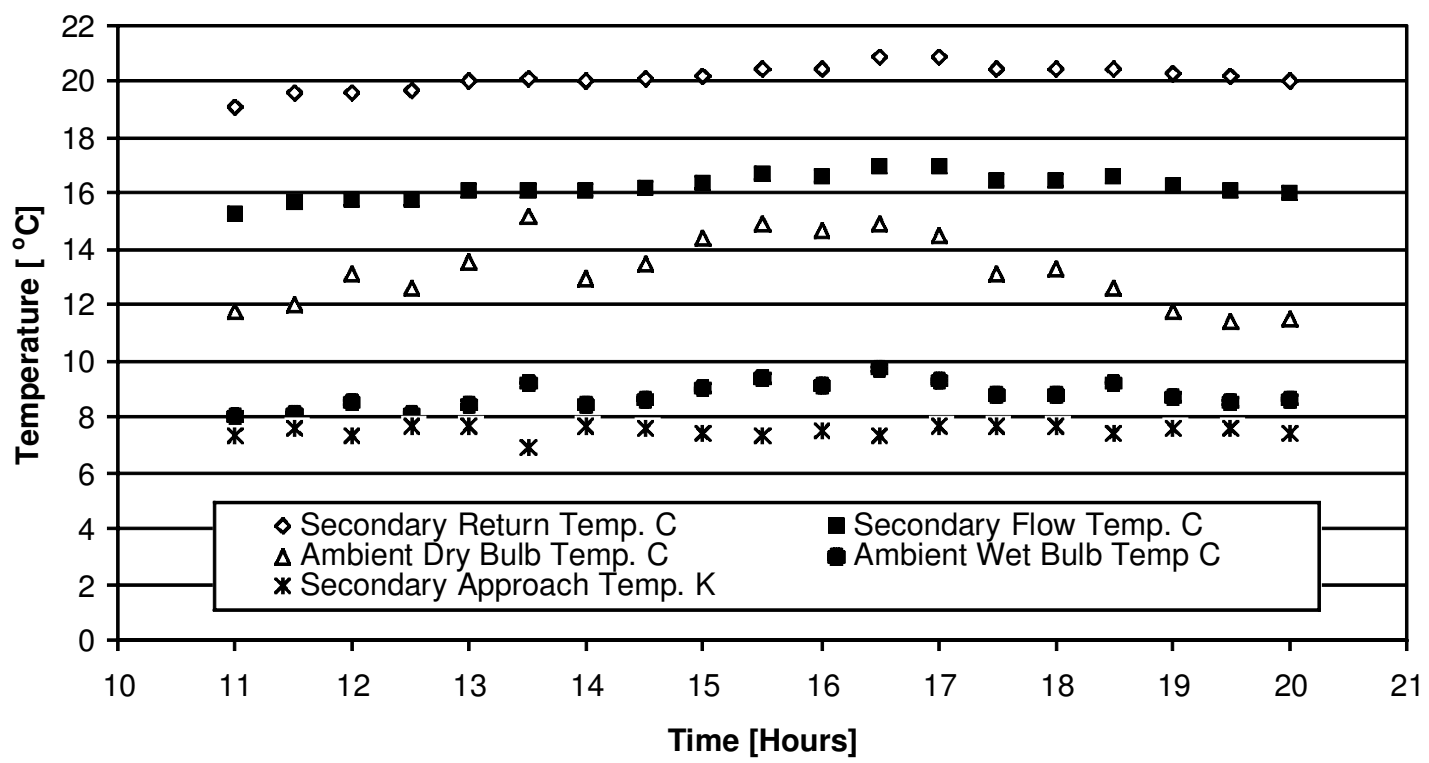

Figure 5 Measured diurnal variation in conditions for 3 May 2001 at a constant $24 \mathrm{~kW}$ load and $32 \%$ fan power input (results of test no. 4)

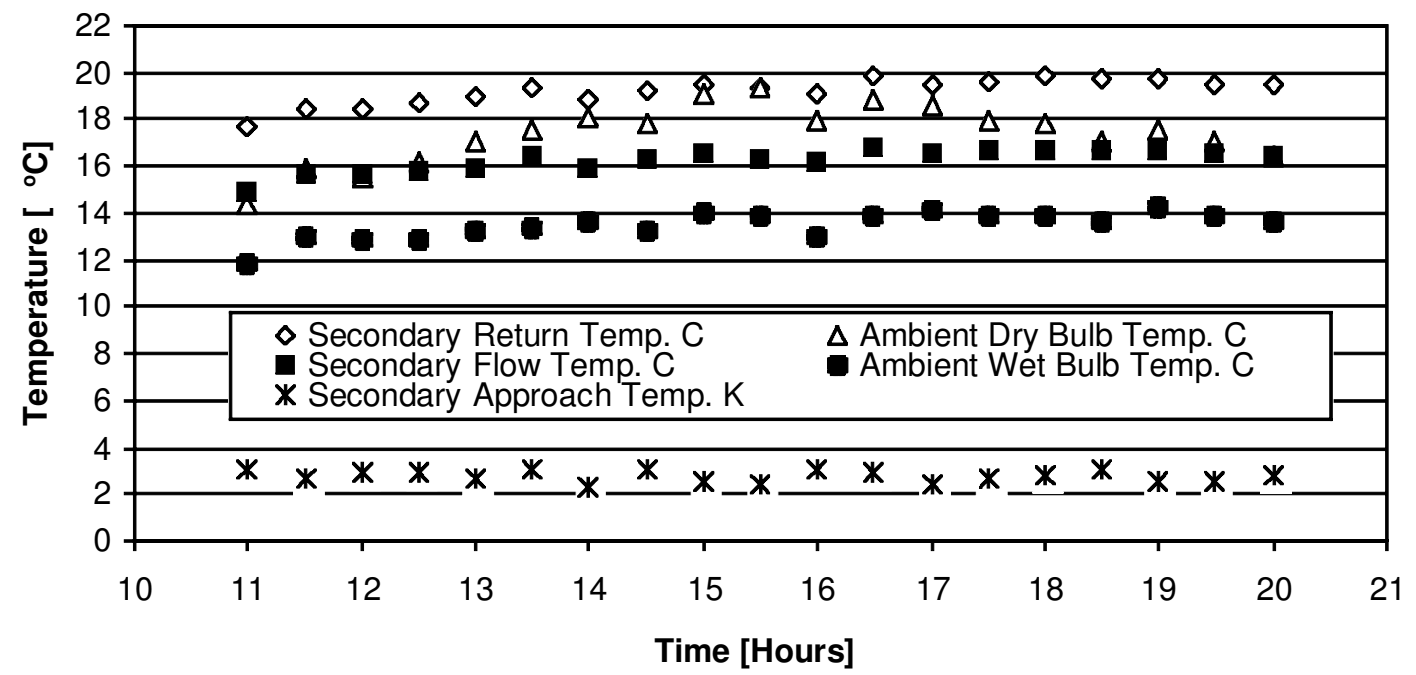

Figure 6 Measured diurnal variation in conditions for 10 May 2001 at constant $17 \mathrm{~kW}$ load and 75\% fan power input (results of test no.7)

cases, is displayed in the consistent linearity of the SAT and seems to be little affected by load or fan power set point. In this respect the close approach tower performs in a manner similar to the conventional wide approach tower for which the dependence of the exiting water temperature on the ambient WBT, is well established. Figures 5 and 6 also demonstrate the effect described by Facao and Oliveira ${ }^{5}$ whereby increases in the wet bulb temperature give rise to small decreases in the approach temperature. It can also be seen, that the effect of increas- 
ing the fan power to $75 \%$, as shown in Figure 6 , is to bring the secondary flow temperature between the ambient DBT and the ambient WBT. Whereas at $32 \%$ fan power the secondary flow temperature achieved is above the ambient dry bulb temperature (as shown in Figure 5) which implies that similar conditions could possibly be achieved with enhanced dry coolers. However, as the ambient WBT is generally far more stable than the ambient DBT (as shown in the diurnal variation in both temperatures in Figures 5 and 6) wet cooling will produce a more stable cooling water temperature and hence is the preferred method of cooling even when it is feasible to produce the required cooling water temperatures by means of dry coolers.

\subsection{Analysis of energy performance}

Figure 7 shows the dependence of the SAT on the cooling tower fan power for the series of 11 tests. The measured data points and the associated power law regression lines are shown in Figures 7 and 8. SAT ranged from approximately 3 to $10 \mathrm{~K}$. The rising SAT (and hence the reduction in the potential for cooling water generation) which results from reducing the fan power input, is clearly demonstrated. For both loads, the initial $40 \%$ reduction in fan power input results in a small $1 \mathrm{~K}$ rise in SAT. Hence significant energy benefits can be gained, initially, for small reductions in cooling potential. However, subsequent reductions in power input result in a steep rise in the approach condition and hence a significant decline in cooling availability in summer.

Figure 8 expresses the relationship between the measured fan power input and the test COP. As shown in Table 3 the possible COP ranged from 5.4 to 20.4. This range of values is comparable with those reported by Hasan and Siren ${ }^{16}$ for closed wet towers for which a possible range of 3-20 was indicated. The results achieved are also comparable with the COP value of 11.4 , reported by the same author, for the optimized closed wet tower. For the $24 \mathrm{~kW}$ full load the COP rises from a minimum of 7.5 at a SAT of $4.4 \mathrm{~K}$ to 20.4 at an approach of $9.4 \mathrm{~K}$. This performance can be compared with the COP levels

\section{Percentage power input}

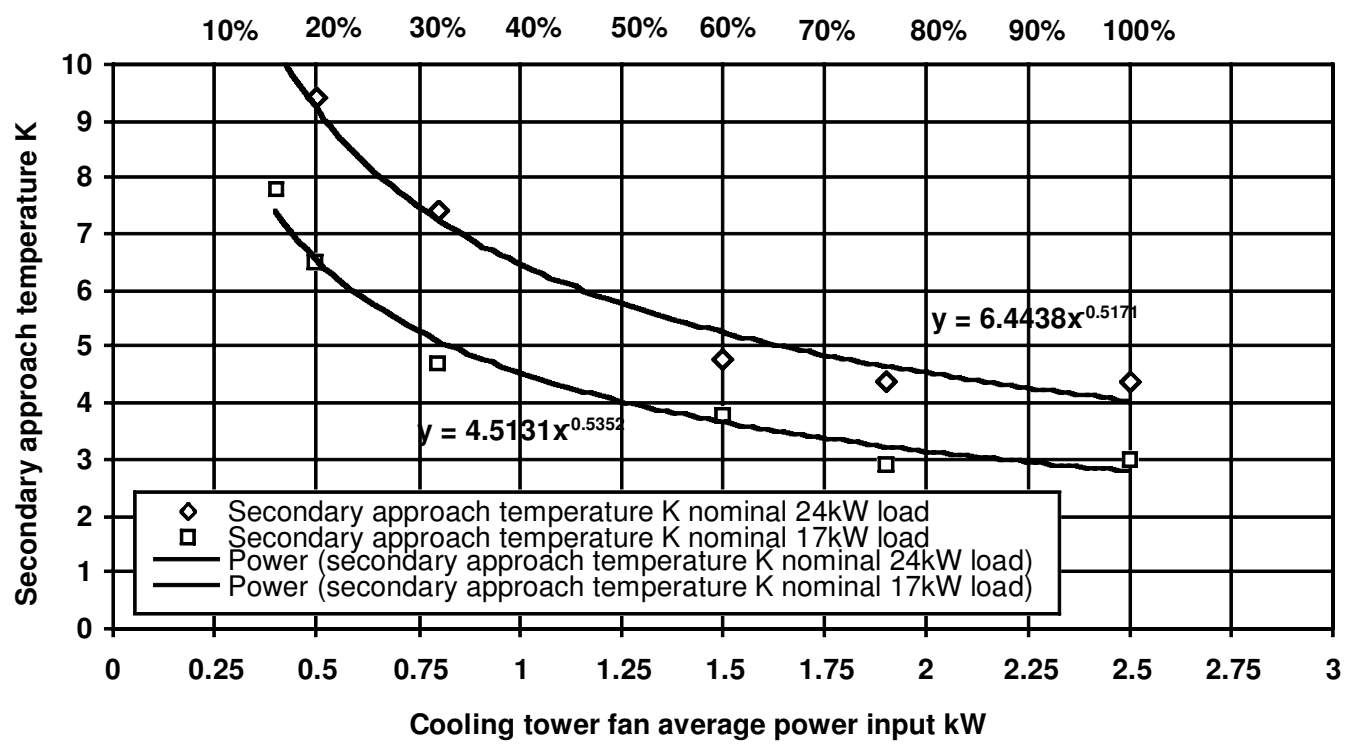

Figure 7 Dependence of the secondary approach temperature on fan power input. Measured data points, associated power law regression lines and regression line equations are shown 


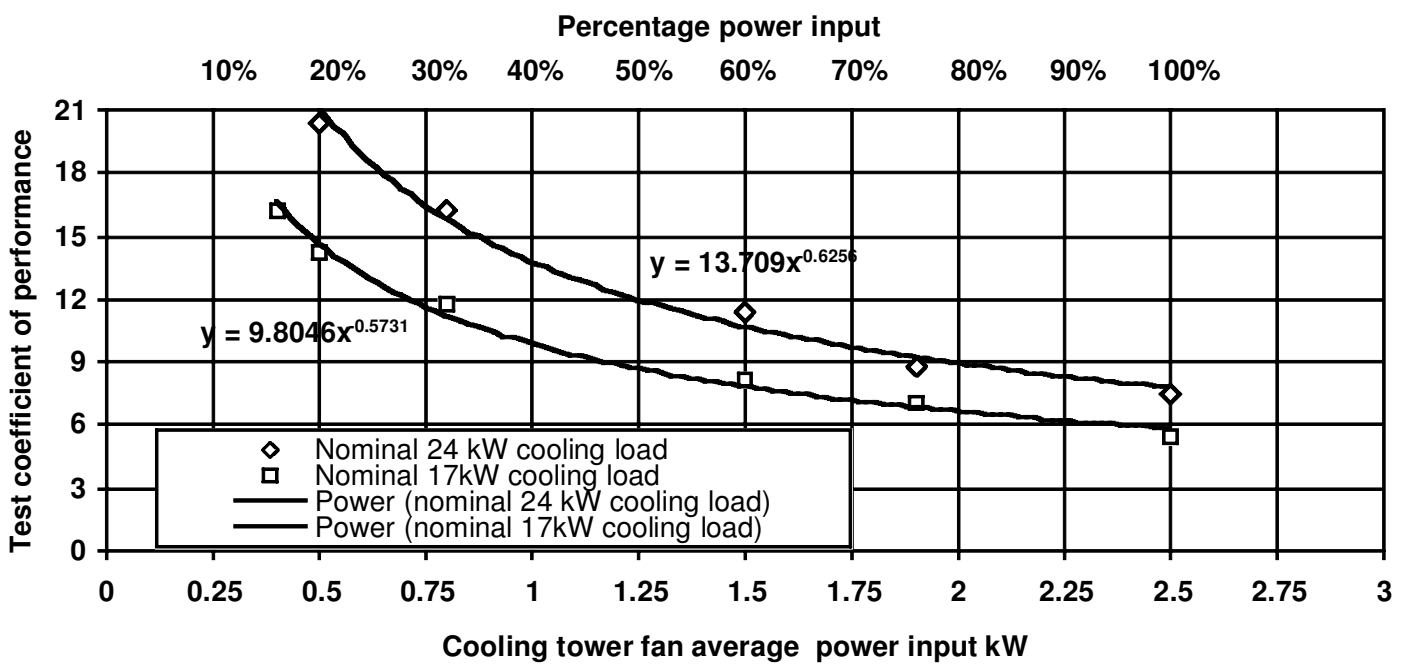

Figure 8 Relationship between fan power input and COP for the test rig. Measured data points, associated power law regression lines and regression line equations are shown

which can be achieved with standard vapour compression systems, which range from 2.8 for small air cooled screw machines to the very best values of 7.0 which are reported for large water cooled centrifugal machines, operating at full load and producing chilled water at conventional temperatures of $5-8^{\circ} \mathrm{C}$, as quoted in a review by Davis et al. ${ }^{19}$ The COP figures quoted in this review exclude power consumption outside of the machine, such as in condenser water pumps and cooling tower fans.

While some modern vapour compression machines (particularly water cooled screw and centrifugal) can display a significant improvement in energy efficiency, at part load, the 17 $\mathrm{kW}$, part load, maximum COP of the evaporative cooling process, at 16.2 is three times the initial $\mathrm{COP}$ at 5.4 and is at least twice the best part load COP, which can be achieved, with current vapour compression systems. The significantly smaller fan power inputs required under higher approach partial load conditions makes possible the achievement of high levels of COP, at lower loads in the nonsummer months, when inverter control of the fan is employed. The results measured are also comparable with the maximum COP of $16.6^{1}$ achieved with wet bulb temperatures below $19^{\circ} \mathrm{C}$ for supply air cooling using a combination of indirect air cooling followed by direct adiabatic cooling in an air stream.

This analysis demonstrates, even with the inclusion of the tower water pump power in the COP assessment, high levels of COP can still be achieved, particularly in the off-peak cooling season. This is significant, as low approach evaporative cooling requires a range temperature approximately half that required for watercooled refrigeration condensers. Hence for similar rates of heat rejection and system design, tower water pumps in low approach evaporative cooling can be up to twice as large as those used in condenser water cooling circuits.

\subsection{Assessment of range of annual energy performance}

In chilled ceilings normal practice is to maintain the supply water temperature approximately constant throughout the year. Hence, as ambient WBT falls, the control strategy is to use the inverter to reduce the air volume flow rate and increase the approach temperature. In this way a constant cooling water temperature is maintained at the optimum COP. Without a strategy, such as this, COP levels will remain at their minimum value, all year and the cooling water temperature will rise and fall as it tracks the 
ambient condition. In this situation the space could be over-cooled and condensation could occur on the chilled ceiling. Knowing the annual statistical frequency of occurrence of each WBT, for each location ${ }^{8}$ it is possible to determine an annualized COP, for a specific cooling water temperature, and hence the range of the annual energy performance can be assessed. Table 4 shows such an analysis for a $15^{\circ} \mathrm{C}$ supply water temperature at a constant $17 \mathrm{~kW}$ cooling load over that portion of the year for which it is feasible to generate this water temperature in Dublin.

The relationship between the fan power input and the SAT can be established from the experimental work, and hence the fan power required at each SAT can be predicted. The primary pump power input is constant at $0.65 \mathrm{~kW}$. For example, for the $17 \mathrm{~kW}$ load, the correlation between the SAT and the fan power input is given by the power law regression equation (see Figure 7 ) as:

$$
T_{\mathrm{sa}}=4.5131 W_{\mathrm{f}}^{-0.5352}
$$

Alternatively, where $W_{\mathrm{f}}$ is required from a known $T_{\mathrm{sa}}$, the equation can be rearranged as:

$$
W_{\mathrm{f}}=10^{-\left[\left(\log \left(T_{\mathrm{sa}} / 4.5131\right)\right) / 0.5352\right]}
$$

These correlations define the relationship between columns 5 and 6 of Table 4 . The analysis in Table 4 shows that, in that portion of a full year (7137 hours), for which it is statistically feasible to generate $15^{\circ} \mathrm{C}$ cooling water in Dublin, a primary energy consumption of $9130 \mathrm{kWh}$ is required to reject a total of $121329 \mathrm{kWh}$. This results in an effective annual COP of 13.3. On the same basis, cooling water generated at $18^{\circ} \mathrm{C}$, at a constant load of $24 \mathrm{~kW}$ requires $10138 \mathrm{kWh}$ to reject $190776 \mathrm{kWh}$ over 7949 hours; an effective annual COP of 18.8. These effective annual COPs would apply, however, only in a building with a constant steady year round cooling load, such as occurs in data processing centres. In most buildings, subject to seasonal and diurnal variations in load the annualized COP would be less than these values. The use of this assessment, therefore, is to define the range and limits of the annual energy performance, at a particular design cooling water temperature, when a variable approach control strategy is employed.

Table 4 Computation of annual energy performance with variable SAT for a constant $15^{\circ} \mathrm{C}$ cooling water generation and $17 \mathrm{~kW}$ load

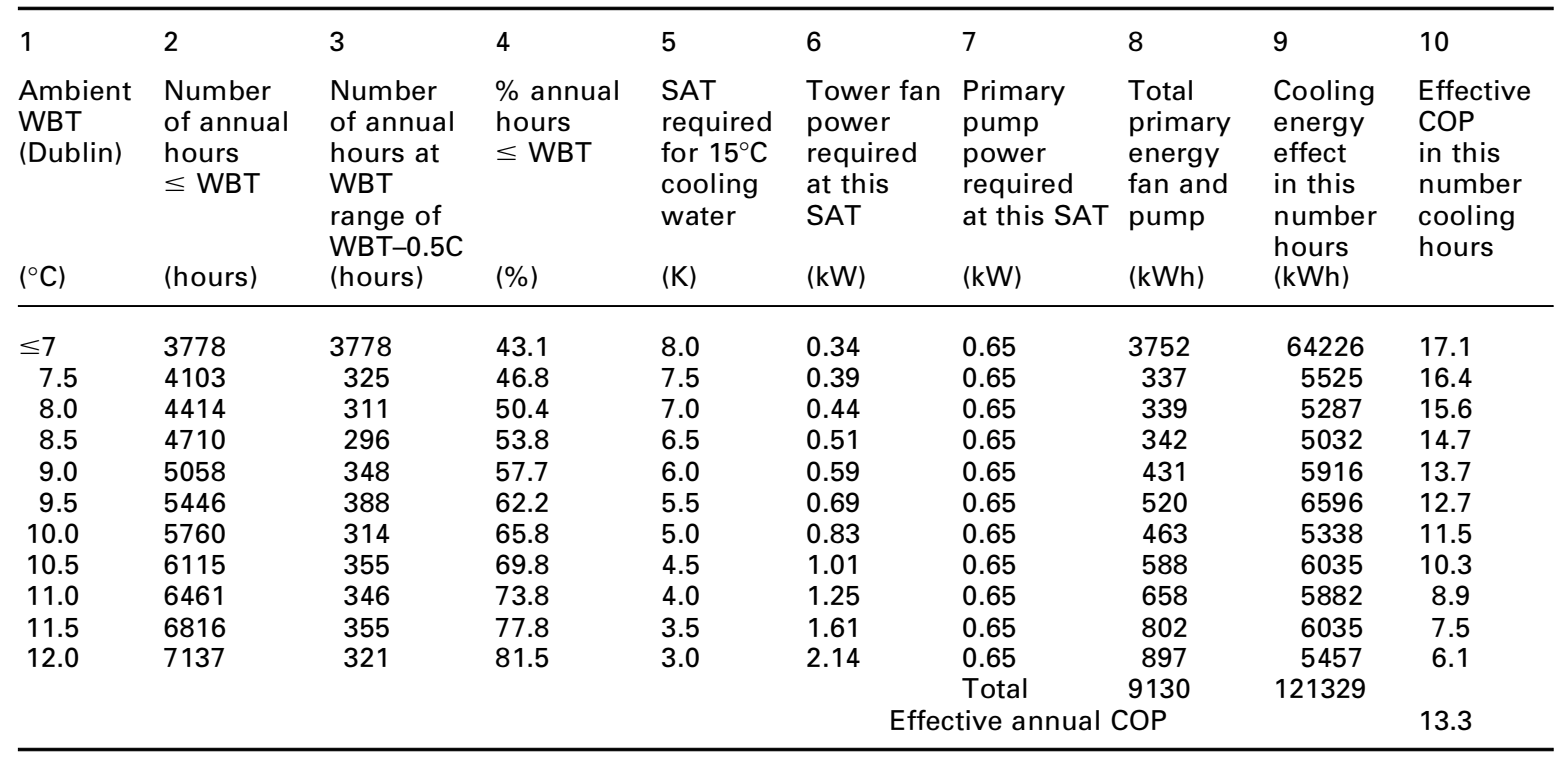




\section{Conclusions}

The results of experimental research into the energy performance of cooling water generation (at temperatures suitable for chilled ceiling applications) in an indirect open cooling tower test rig, have been presented and discussed. The research indicates that the energy performance is significantly superior to that of modern vapour compression plants in general and to air cooled reciprocating plants in particular. The following specific conclusions can be drawn:

1) At a full load of $24 \mathrm{~kW}$, as shown in Table 3 and with a SAT ranging from 4.4 to $4.8 \mathrm{~K}$, a COP ranging from 7.5 to 11.4 was achieved, with primary circuit pump energy included in the COP calculation. These COP values are above the very best values of 7.0 which are reported for large, vapour compression, water cooled, centrifugal machines and are considerably better than the standard reciprocating air cooled machine for which COP values in the order of 4.0 are typical. At these approach conditions the total annual availability of cooling water at $18^{\circ} \mathrm{C}$ is approximately $90 \%$ in Dublin and $83 \%$ in London.

2) At a partial load of $17 \mathrm{~kW}$ and with a SAT ranging from 2.9 to $3.8 \mathrm{~K}$, a COP ranging from 5.4 to 8.1 was achieved, with primary circuit pump energy included in the COP calculation. Hence at very low approach and partial load conditions the COP levels approach the values reported for modern large high efficiency water cooled vapour compression plants. At these approach conditions the total annual availability of cooling water at $15^{\circ} \mathrm{C}$ is approximately $80 \%$ in Dublin and $72 \%$ in London.

3) When advantage is taken of a falling ambient WBT, while generating a constant temperature cooling water, considerable reductions can be achieved in the annual energy consumption. For a constant $18^{\circ} \mathrm{C}$ cooling water generation, in Dublin, at a steady load of 24 $\mathrm{kW}$, the annualized (over the 7949 hours available) COP is 18.8 and for a constant $15^{\circ} \mathrm{C}$ cooling water generation, at a steady load of $17 \mathrm{~kW}$, the annualized (over the 7137 hours available) COP is 13.3. These values indicate the limits of the process, rather than typical values, which could be achieved. To achieve high levels of annual COP therefore, it is necessary to incorporate stepless control of the cooling tower fan speed, in a manner, which automatically tracks the ambient enthalpy condition. Similar and interlocked control of the primary water pump is also desirable. Further research is required to develop a control optimization analysis of the fan and primary pump energy usage.

4) The COP achieved in this work are comparable with those reported recently in a computational modelling study on closed wet towers, in this application. In this work possible COP levels ranging from 3 to 20 were indicated, with a value of 11.4 for a closed tower design, optimized for energy efficiency.

5) The high COP levels which can be achieved in the off-peak cooling season implies that the chilled ceiling, supplied by evaporatively generated cooling water, is particularly suited to applications with long cooling seasons and steady, sensible, internal, cooling loads. Such load profiles increasingly occur in the current generation of commercial buildings, constructed with a high performance envelope.

6) As the diurnal variation in WBT (typically $3{ }^{\circ} \mathrm{C}$ in Dublin) is less than similar variations in the ambient DBT (typically $7^{\circ} \mathrm{C}$ in Dublin), the evaporative process produces a significantly more stable diurnal cooling water temperature and hence is the preferred means of generating cooling water for chilled ceiling applications, even during those periods when it is feasible to use dry air coolers.

7) While the research results are based on experimental measurement the test rig has been constructed to a semi-industrial scale, using currently available cooling tower, heat exchanger and energy efficient control technology. A building cooling system, therefore, constructed along similar lines and based on the design conditions incorporated in the rig, 
could be expected to achieve similar results-a minimum secondary approach condition of $3 \mathrm{~K}$ and COP levels ranging from 6 to 12, depending on percentage load and ambient WBT.

\section{Acknowledgements}

This work has been supported by a research grant from the CIBSE (Republic of Ireland branch), Enterprise Ireland, and the Dublin Institute of Technology (DIT). Private companies also donated equipment and their generous support is gratefully acknowledged, as is the support of the laboratory staff of the Department of Building Services Engineering, DIT.

\section{References}

1 Tassou S, editor. Low-energy cooling technologies for buildings. London: IMech E, 1998.

2 Watt JR. Evaporative air conditioning handbook. New York: Chapman and Hall, 1986.

3 CIBSE. Chilled ceilings and beams:CIBSE research report RR5. CIBSE: London, 1998.

4 Gan G, Riffat SB, Shao L. Performance prediction of a prototype closed wet cooling tower. J Inst Energy 2000; 73: 106-13.

5 Facao J, Oliveira AC. Thermal behaviour of closed wet cooling towers for use with chilled ceilings. Applied Thermal Engineering 2000; 20: 1225-36.

6 Owen G, King G. High capacity chilled ceilings. Building Services Journal 2001; No. 3: 47.

7 Roulet CA, Rossy JP, Roulet Y. Using large radiant panels for indoor climate conditioning. Energy and Buildings 1999; 30: 121-26.
8 Costelloe B, Finn D. Indirect evaporative cooling potential in air-water systems in temperate climates. Energy and Buildings 2003; 35: 573-91.

9 Behne M. Indoor air quality in rooms with cooled ceilings - mixing ventilation or rather displacement ventilation. Energy and Buildings 1999; 30: 155-66.

10 Costelloe B, Finn D. Evaporative cooling availability in water based sensible cooling systems. Proceedings of CLIMA World Congress, Naples, September 2001.

11 ASHRAE. ASHRAE Handbook: Fundamentals. ASHRAE: Atlanta, GA, 1997.

12 CIBSE. Minimising the risk of Legionnaires' disease, TM13. CIBSE: London, 2000.

13 De Saulles T. Free cooling systems. BSRIA: Bracknell, UK, 1996.

14 Field J. Building analysis - 1 City Square Leeds. Building Services Journal 1998; 12: 1418.

15 Murphy D. Cooling towers for free cooling. ASHRAE Journal 1991; June: 16-26.

16 Hasan A, Siren K. Theoretical and computational analysis of closed wet cooling towers and its application in cooling of buildings. Energy and Buildings 2002; 34: 47786.

17 Costelloe B, Finn D. The design and performance of an evaporative cooling test rig for a maritime climate. Proceedings of Joint CIBSE/ASHRAE Conference, Dublin, September 2000; 830-45.

18 Butler DJG. Chilled ceilings-a free cooling opportunity. Proc. CIBSE National conference 1998, Bournemouth, UK, 1998; 273-79.

19 'Davis Langdon and Everest'. Chillers cost model. Building Services Journal 1999; No.12: 13-14. 